\title{
Rancang Bangun Aplikasi Marketplace Tour dan Travel Di Kota Semarang
}

\author{
Muhammad Syahrul Rizal ${ }^{1}$, Veri Julianto ${ }^{2)}$ \\ 1)2) Jurusan Teknik Informatika, Politeknik Negeri Tanah Laut \\ Jl. A Yani Km 6 Pelaihari Tanah Laut Kalimantan Selatan \\ ${ }^{1)}$ muhammadsyahrulrizal98@gmail.com \\ ${ }^{2)}$ verijulianto@gmail.com
}

\begin{abstract}
Abstrak
Banyak masyarakat yang masih kesulitan dalam melakukan pencarian paket wisata yang sesuai dengan kantong mereka. Masyarakat banyak mencari diberbagai website akan tetapi mereka masih kesulitan dalam melakuan perbandingan harga untuk penyedia tour travel yang berbeda. Keberadaan aplikasi marketplace ini dibuat dengan tujuan membantu masyarakat untuk mencari paket perjalanan wisata dari berbagai tour travel yang tersedia, sehingga memudahkan masyarakat untuk mencari paket perjalanan sesuai kondisi keuangan dan keinginan mereka. Aplikasi ini dibuat dengan menggunakan bahasa pemrograman PHP dan MySQL sebagai database-nya. Metode pengembngan sistem pada pembuatan aplikasi ini menggunakan metode design sprint. Berdasarkan pengujian yang dilakukan kepada pengguna, aplikasi ini secara fungsionalitas berjalan sesuai dengan yang diharapkan dan tingkat keberhasilannya yaitu $92 \%$.
\end{abstract}

Kata kunci: Aplikasi, Marketplace, Design Sprint, Travel

\begin{abstract}
Many people are still having difficulty in searching for travel packages that fit their pockets. Many people are looking for various websites but they are still having difficulties in making price comparisons for different travel tour providers. The existence of this marketplace application is made with the aim of helping people to find travel packages from various available travel tours, making it easier for people to find travel packages according to their financial conditions and desires. This application is created using the PHP programming language and MySQL as the database. The stages of making this application use the sprint design method. Based on the tests carried out to the user, this application is functionally running as expected and the success rate is $92 \%$.
\end{abstract}

Keywords: Application, Marketplace, Design Sprint, Travel

\section{PENDAHULUAN}

Era globalisasi merupakan sebuah era yang dimana masyarakat memerlukan suatu informasi secara cepat, mudah, hemat, tepat, efektif dan efesien waktu. Selain itu aplikasi yang dimaksud juga dapat diakses dimana saja. Sekarang ini banyak bermunculan aplikasi-aplikasi yang memberikan layanan terhadap hal tersebut seperti pembelian makanan, minuman, barang kebutuhan pokok, tiket pesawat, tiket hotel, transportasi dan lainnya secara online. Salah satu bidang yang menggunakan aplikasi tersebut yaitu pada bidang pariwisata. Aplikasi-aplikasi di bidang ini telah memberikan banyak manfaat dan kemudahan untuk setiap kegiatan akan tetapi masih banyak masalah-masalah yang masih belum diselesaikan seperti belum terhimpunnya penyedia layanan tour travel bagi masyarakat secara menyeluruh sehingga masih banyak masyarakat kebingungan dalam mencari tour travel dengan mudah dan sesuai dengan kondisi keuangan yang tersedia. Penyedia tour travel juga memiliki masalah dalam melakukan pemasaran produk-produk mereka secara global karena belum tersedia tempat pemasaran untuk skala global. 
Penyedia tour travel yang belum terhimpun menjadi penyebab sulitnya mendapatkan informasi tentang paket wisata yang sesuai kondisi yang diinginkan oleh masyarakat, sehingga perlunya dibangun sebuah aplikasi yang dimana masyarakat dapat langsung memesan dan memilih tour travel serta tujuan wisata yang mereka inginkan. Mereka juga secara langsung dapat berkomunikasi dengan penyedia tour travel tersebut tanpa harus bertemu secara langsung sehingga dengan mudah menentukan tujuan wisata mereka sesuai kondisi keuangan yang tersedia. Mereka juga tidak perlu mengerluarkan banyak waktu untuk mencari penyedia tour travel tersebut dan juga penyedia tour travel akan dimudahkan dalam pemasaran produk-produk mereka.

Berdasarkan latar belakang permasalahan tersebut maka jurnal ini mengangkat judul "Rancang Bangun Aplikasi Marketplace Tour dan Travel Di Kota Semarang”. Aplikasi Marketplace tersebut diharapkan dapat membantu dan memudahkan masyarakat dalam menentukan tujuan wisata sesuai dengan keinginan mereka serta diharapkan dapat membantu penyedia tour travel dalam melakukan pemasaran produk-produk mereka secara global.

\section{TINJAUAN PUSTAKA}

Berikut ini beberapa teori pendukung dalam melakukan penulisan jurnal ini:

\subsection{Paket Wisata}

Paket wisata merupakan suatu perjalanan wisata dengan satu atau lebih tujuan yang di susun dalam suatu rencana perjalanan yang tepat, yang dijual dengan harga yang tunggal. Dalam memahami paket wisata, harus dipastikan bahwa rangkaian kompnen wisata tersebut terdapat mengunjungi objek wisata. Jika hanya paket perjalanan transportasi dan akomodasi saja, maka belum bisa dikatakans sebagai paket wisata (Brahmanto, 2015).

\section{$2.2 \quad$ Vue Js}

Vue.js adalah suatu library Javascript yang digunakan untuk membangun antar muka sebuah website yang interaktif. Vue difokuskan hanya pada view layer sehingga sangat mudah diimplementasikan dan diintegrasikan dengan library lain ataupun juga dengan project yang sudah ada sebelumnya. Mempelajari Vue ini setidaknya harus sudah mengerti dasar-dasar HTML, CSS dan juga Javascript (Djirdeh, 2018).

\subsection{Design Sprint}

Design Sprint merupakan sebuah kerangka kerja yang dibatasi oleh waktu yang menggunakan konsep Design Thinking (DT) untuk membantu sekelompok orang membuat sebuah product baru, layanan atau fitur. Design Sprint terdiri dari 5 tahap yaitu understand, coverge, diverge, prototype dan test (Silva, et al., 2017).

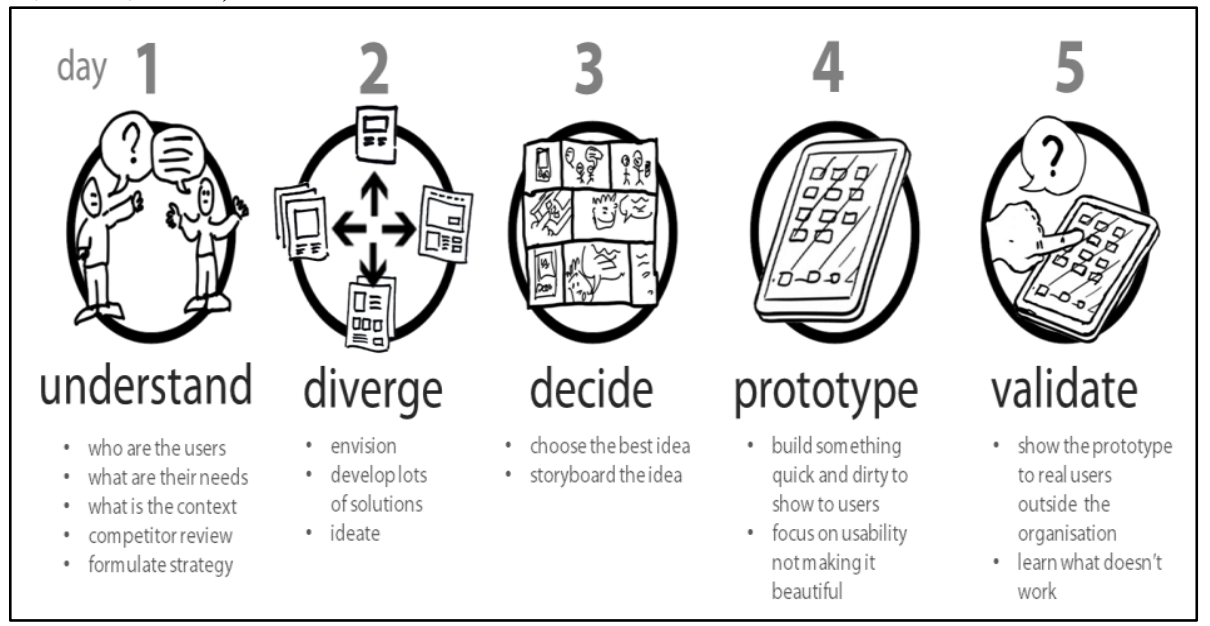

Sumber: (Banfield, et al., 2016)

Gambar 1 Contoh metode Design Sprint 


\subsection{UML (Unified Modeling Language)}

Pada perkembangan teknik pemograman berorientasi objek, munculah sebuah standarisasi bahasa pemodelan untuk pembangunan perangkat lunak yang dibangun dengan menggunakan teknik pemograman berorientasi objek yaitu Unified Modeling Language (UML). UML (Unified Modeling Language) muncul karena adanya kebutuhan pemodelan visual untuk menspesifikasikan, menggambarkan, membangun, dan dokumentasi dari sistem perangkat lunak. UML (Unified Modeling Language) merupakan bahasa visual untuk pemodelan dan komunikasi mengenai sebuah sistem dengan menggunakan diagram dan teks-teks pendukung (Sukamto \& Shalahuddin, 2016).

\section{METODE PENELITIAN}

\subsection{Metode Pengumpulan Data}

Tahap pengumpulan data merupakan suatu proses untuk menguraikan data yang didapat untuk menyelesaikan masalah pada saat pembuatan aplikasi. Tahap pengumpulan data dilakukan dengan 2 cara yaitu:

\subsubsection{Studi Kepustakaan}

Pada tahap studi kepustakaan penulis mengumpulan data yang dilakukan dengan cara memanfaatkan berbagai macam informasi serta metode-metode dari buku, jurnal, artikel dari website, dan lain-lain yang berhubungan dengan aplikasi yang sedang dibuat.

\subsubsection{Wawancara}

Pada tahap wawancara penulis berdialog atau tanya jawab dengan beberapa orang atau karyawan pada penyedia tour travel mengenai aplikasi yang akan dibuat sehingga diperoleh data yang sesuai keadaan yang sebenarnya.

\subsection{Metode Design Sprint}

Dalam melakukan pengembangan sistem mengunakan metode design sprint yaitu :.

a. Understanding

Pada tahap ini dilakukan proses user interview pada beberapa penyedia tour travel di Kota Semarang. Selain itu juga dilakukan proses brenchmark dengan situs-situs serupa.

b. Diverge

Pada tahap ini akan dilakukan proses pencarian solusi terhadap permasalahan penyedia tour travel. Sehingga ditemukan strategi dan batasan aplikasi yang akan di buat.

c. Decide

Pada tahap ini bersama dengan tim pengembang melakukan diskusi dengan mengeluarkan ide-ide yang disampaikan ke pihak penyedia tour travel, dimana ide yang terbanyak peminatnya itu yang akan di eksekusi.

d. Prototype

Pada tahap tim pengembang aplikasi membuat tampilan mockup digital dengan kodingan dengan mencoba data yang dummy. Pada tahap ini juga dilakukan demo kepada penyedia tour travel sehingga hasilnya nanti sesuai dengan yang diharapkan

e. Validate merupakan tahap uji coba tampilan dan fitur yang dibuat kemudian akan di review bersama client tentang keunggulan dan kelemahan fitur tersebut. 


\section{PEMBAHASAN}

Berikut adalah Pembahasan analisis sistem yang berjalan sampai dengan implementasi aplikasi.

\subsection{Analisis Sistem yang Berjalan}

Analisis sistem yang berjalan dapat dilihat pada:

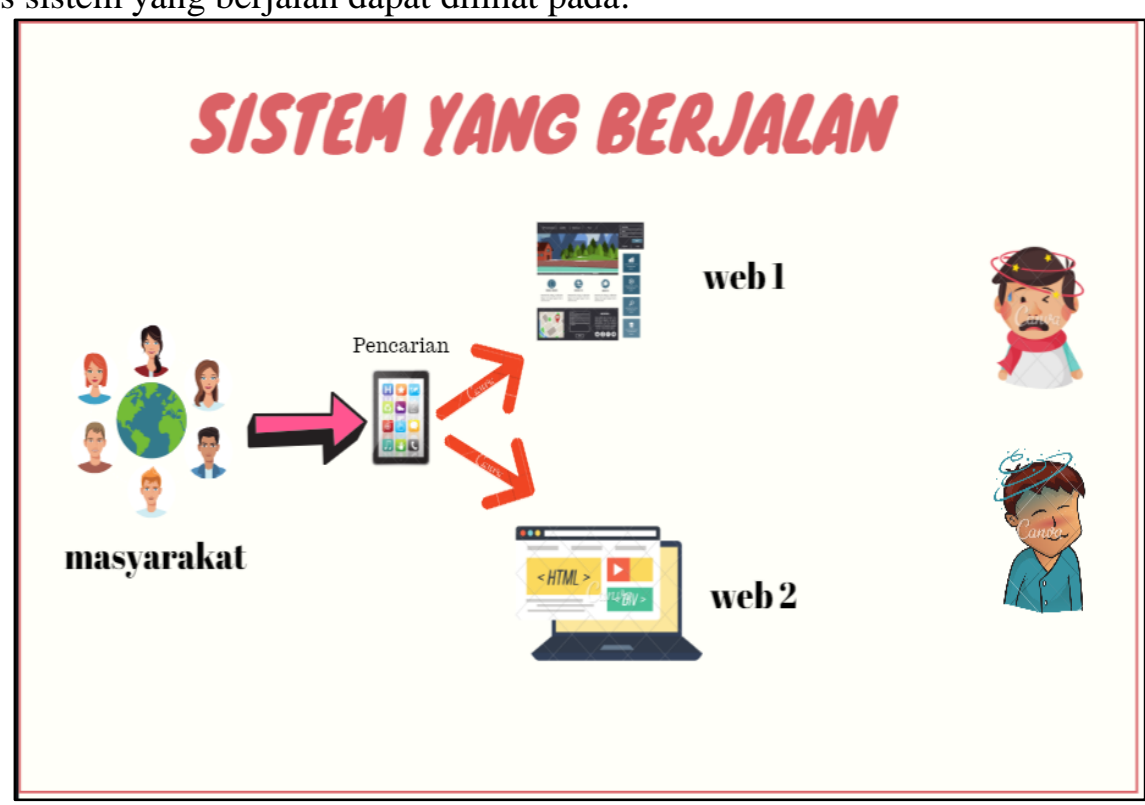

Gambar 2. Sistem yang berjalan

Gambar 2 adalah sistem yang sedang berjalan dimana masyarakat melakukan pencarian di berbagai website terkait tempat wisata dikarenakan belum adanya info yang mengumpulkan penyedia travel dalam satu akun.

\subsection{Analisis Sistem yang Diusulkan}

Analisis sistem yang diusulkan dapat dilihat pada Gambar 3.

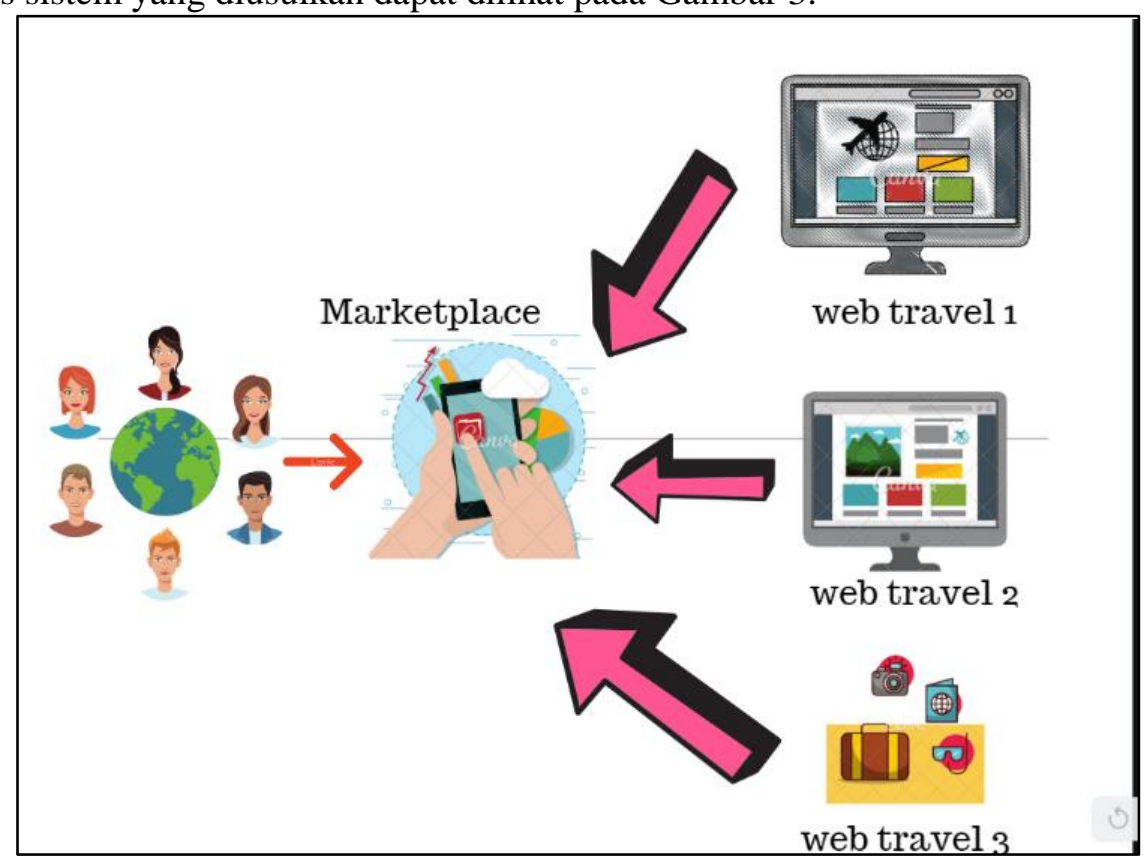

Gambar 3. Sistem yang diusulkan 
Gambar 3 adalah sistem yang diusulkan oleh penulis adalah sebuah aplikasi terintegrasi yang menggabungkan artikel yang ada di website dengan paket-paket produk tour travel.

\subsection{Entity Relationship Diagram (ERD)}

Berikut adalah rancangan ERD pada Aplikasi Marketplace Pariwisata, dapat dilihat pada gambar 4.

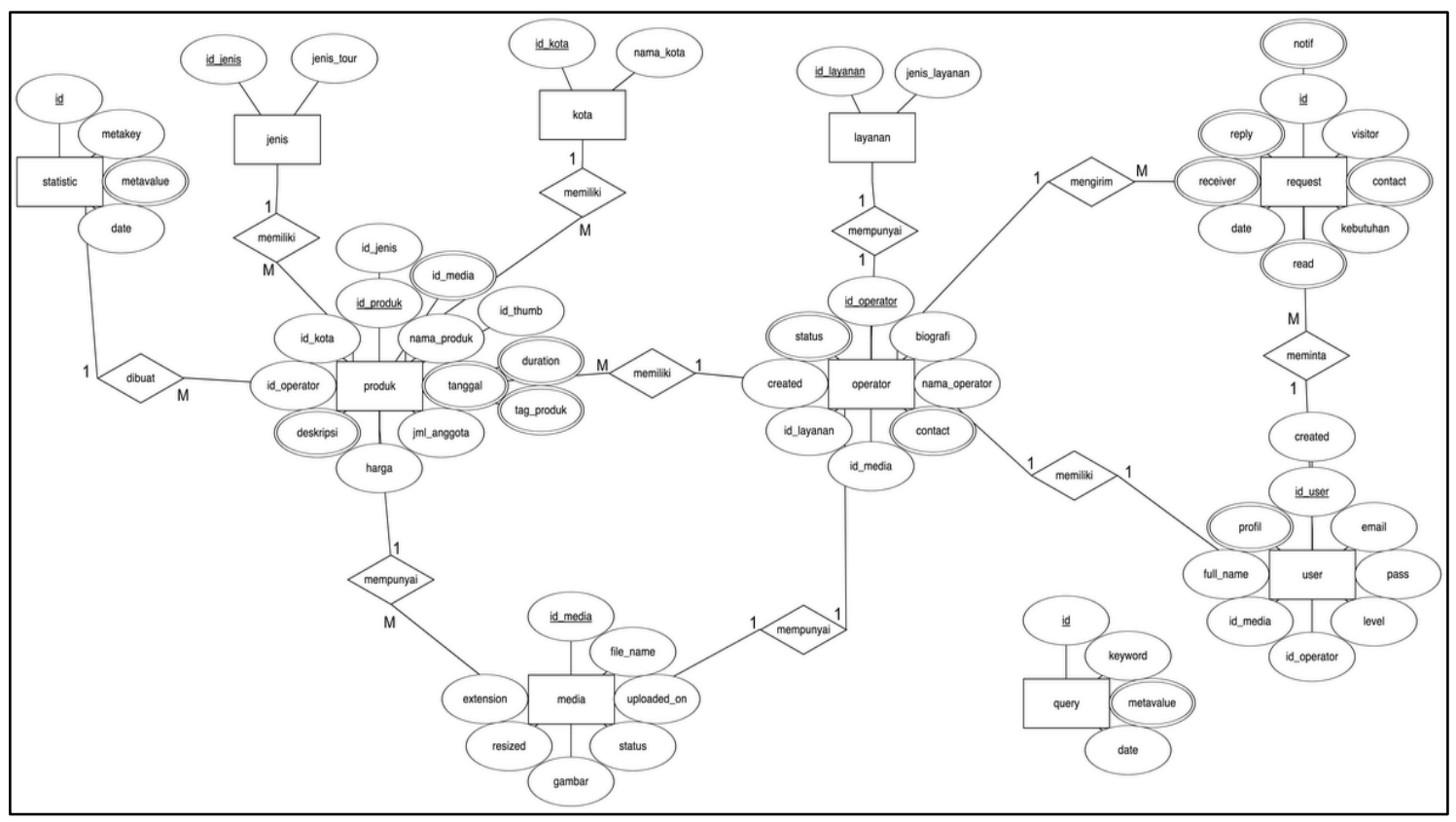

Gambar 4. Entity Relationship Diagram (ERD)

Gambar 4 adalah alur database yang terdiri atas sepuluh entitas, setiap entitas mewakili nama tabel yang ada di database Aplikasi Marketplace Pariwisata. Setiap atribut yang ada mewakili kolom-kolom yang ada pada database. Relasi yang menghubungkan entitas-entitas sesuai peranannya, bobot peranan entitas dapat dilihat pada kardinalitasnya.

\subsection{Rancangan Unified Modeling Language (UML)}

Perancangan Aplikasi Marketplace tour dan travel di Semarang adalah dengan menggunakan Unified Modelling Language (UML) yang terdiri dari 2 diagram yaitu Use case diagram dan Activity diagram.

\subsubsection{Use Case Diagram}

Use case diagram merupakan gambaran fungsional yang diharapkan pada sebuah sistem. Pada use case diagram yang dijelaskan apa saja yang terjadi pada sistem dan apa yang dapat dilakukan Aktor terhadap sistem. Diagram ini juga mempresentasikan suatu interaksi antar actor dengan sistem. 


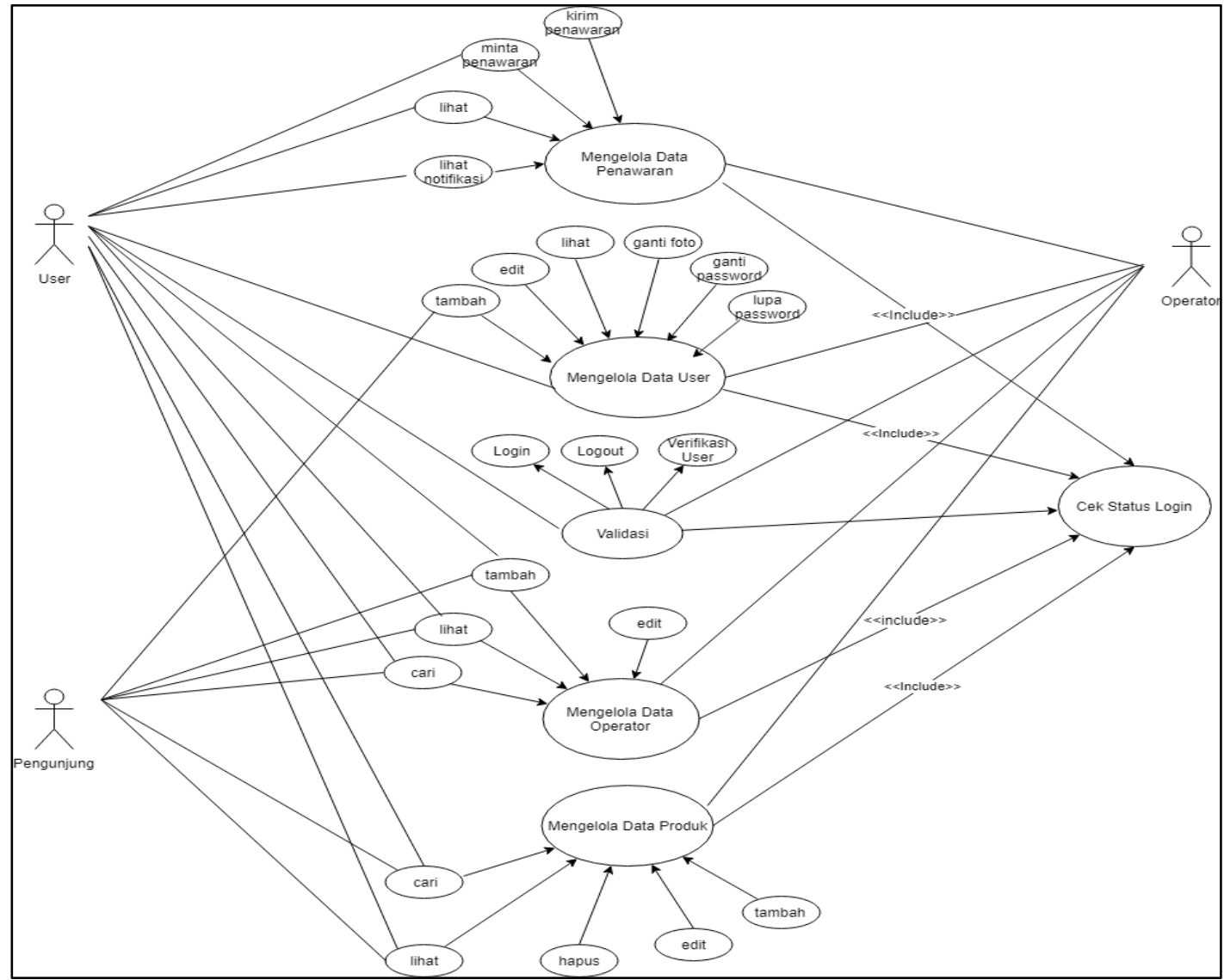

Gambar 5. Use Case

\subsubsection{Activity Diagram}

Diagram aktivitas menggambarkan workflow (aliran kerja) atau aktivitas dari sebuah sistem atau proses bisnis. Berikut adalah activity diagram dari Aplikasi:

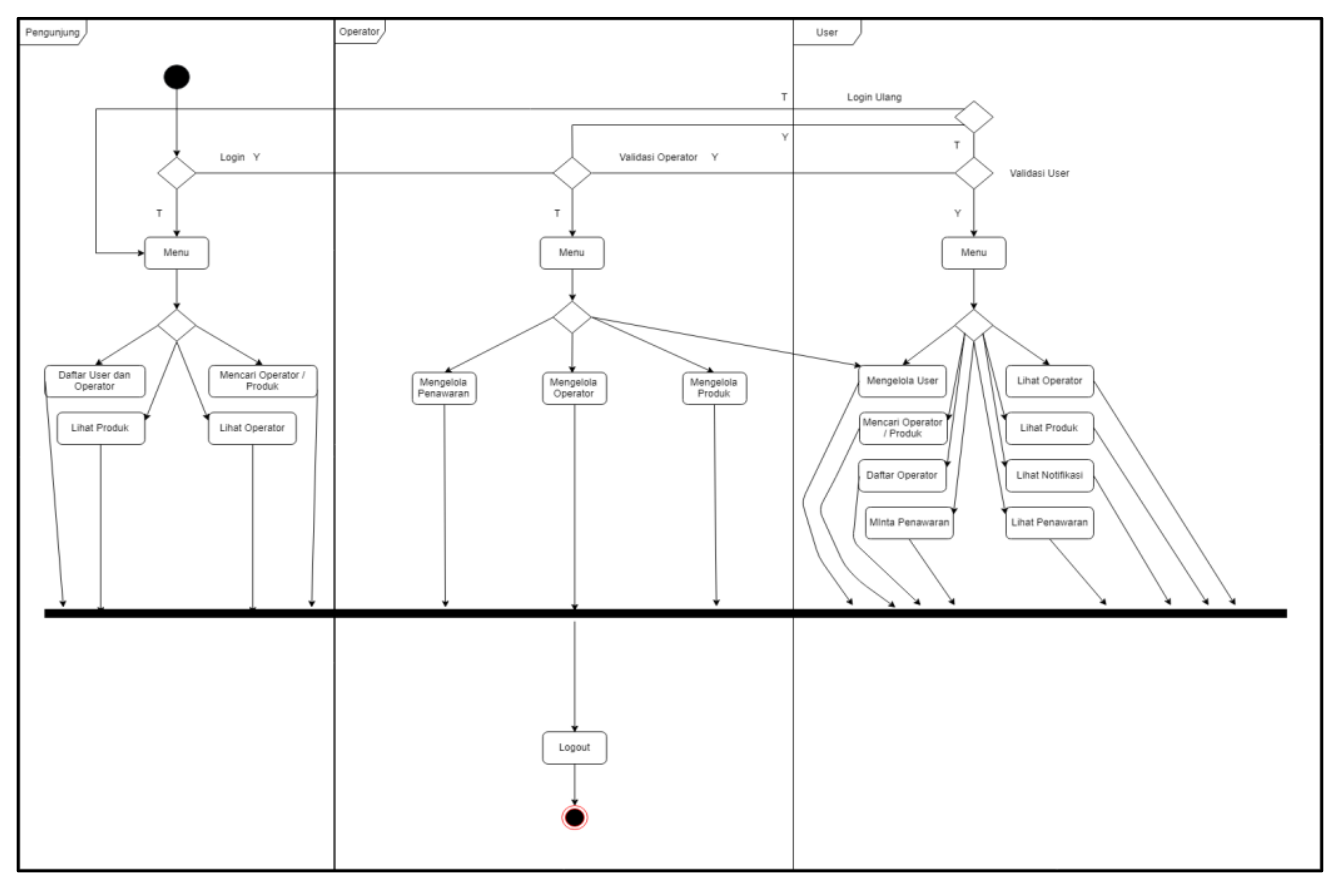

Gambar 6. Activity Diagram 


\subsection{Implementasi Aplikasi}

Berikut adalah implementasi dari Aplikasi Marketplace Pariwisata, dapat dilihat pada Gambar 6.

\subsubsection{Antarmuka Login}

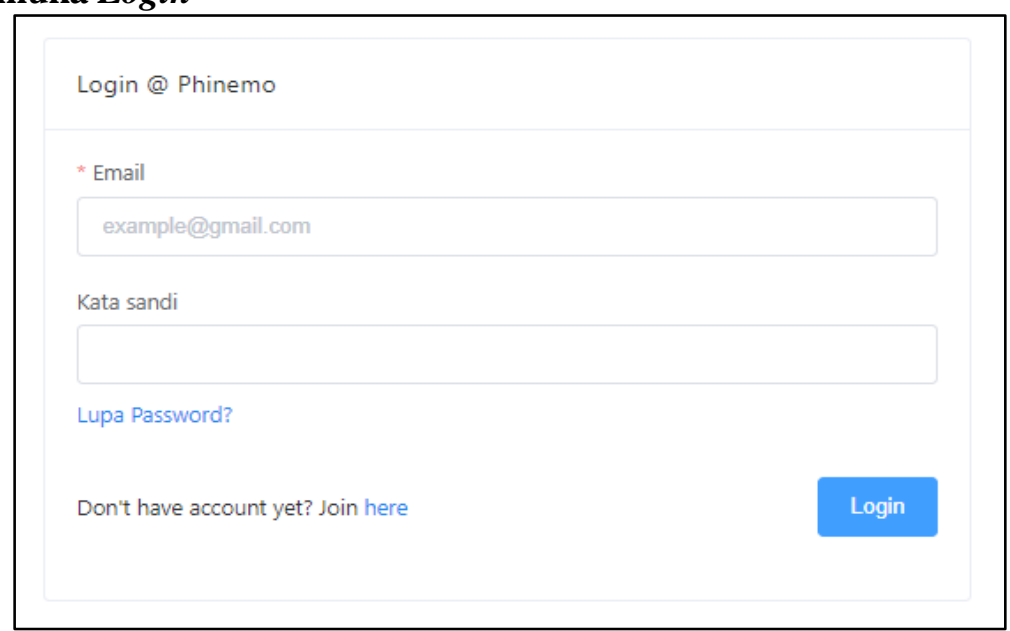

Gambar 7. Implementasi antarmuka login

Gambar 7 adalah antarmuka form login user yang dalam prosesnya user memasukkan data username dan password apabila benar maka akan masuk ke tampilan profile, sedangkan jika salah maka akan tampil peringatan bahwa username dan password salah sehingga user kembali ke form login dan memasukkan data dengan benar.

\subsubsection{Antarmuka Halaman Utama Marketplace}

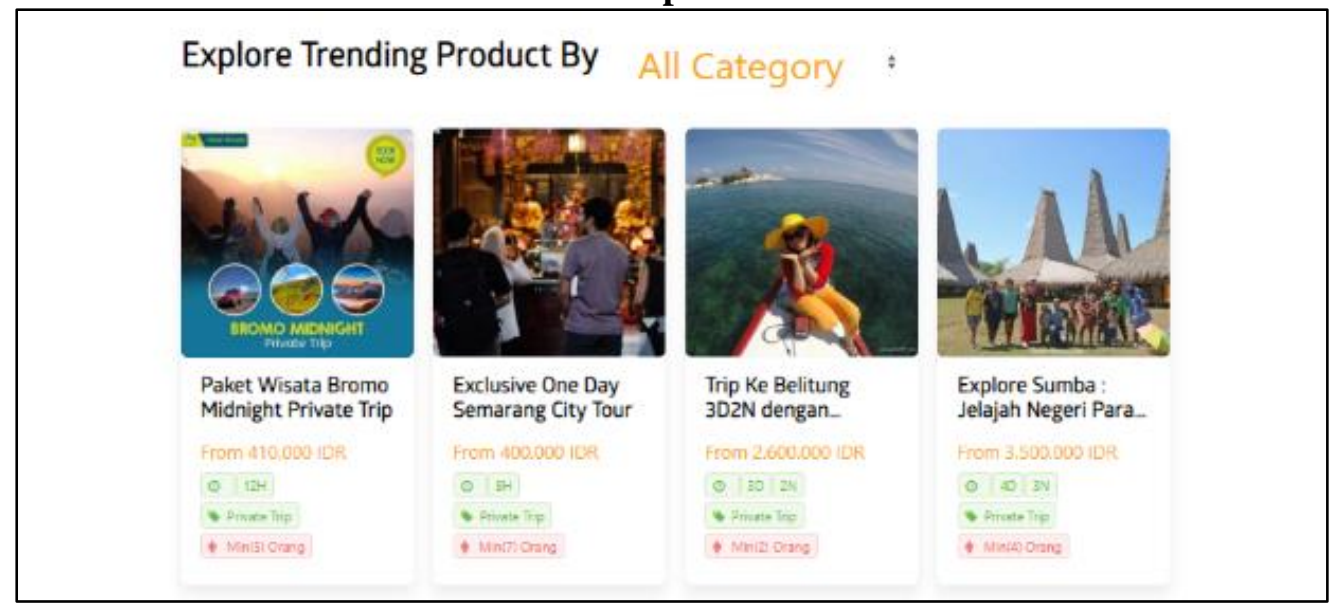

Gambar 8. Antarmuka halaman utama marketplace

Gambar 8 adalah antarmuka halaman utama aplikasi Marketplace Pariwisata yang akan muncul ketika user masuk ke halaman Marketplace pertama kali. Data yang ditampilkan pada halaman tersebut berupa sebuah banner yang terdapat 3 tombol yaitu tombol cari produk berfungsi melakukan pencarian, tombol minta penawaran berfungsi untuk melakukan penawaran kepada operator akan tetapi user harus login dan terverifikasi terlebih dahulu dan tombol daftar sebagai operator berfungsi untuk mendaftarkan diri sebagai user dan juga sebagai operator kemudian terdapat data produk yang telah di kategorikan dan tombol explore more berfungsi untuk melakukan pencarian. 


\subsection{Pengujian Sistem}

Pengujian fungsional Aplikasi Phinemo Marketplace menggunakan metode Black box testing yaitu metode pengujian yang berfokus pada spesifikasi fungsional dari aplikasi.

Tabel 1. Sekenario pengujian sistem

\begin{tabular}{|c|c|c|c|c|}
\hline No. & Skenario Pengujian & Hasil Diinginkan & Hasil Dicapai & Kesimpulan \\
\hline 1 & $\begin{array}{l}\text { User memasukkan } \\
\text { Username dan password } \\
\text { dengan benar }\end{array}$ & $\begin{array}{l}\text { User masuk ke halaman } \\
\text { profile }\end{array}$ & $\begin{array}{l}\text { User dapat masuk ke } \\
\text { halaman profile }\end{array}$ & Berhasil \\
\hline 2 & $\begin{array}{l}\text { User melakukan fitur } \\
\text { lupa password dan } \\
\text { memasukkan email yang } \\
\text { telah terdaftar }\end{array}$ & $\begin{array}{l}\text { User mendapatkan email } \\
\text { yang berisi password baru }\end{array}$ & $\begin{array}{l}\text { User mendapatkan } \\
\text { email yang berisi } \\
\text { password baru }\end{array}$ & Berhasil \\
\hline 3 & $\begin{array}{l}\text { Pengguna melakukan } \\
\text { pendaftaraan } U \text { ser }\end{array}$ & $\begin{array}{l}\text { Pengguna dapat masuk ke } \\
\text { halaman profile dan data } \\
\text { pengguna tersimpan }\end{array}$ & $\begin{array}{l}\text { Pengguna dapat } \\
\text { masuk ke halaman } \\
\text { profile dan data } \\
\text { pengguna tersimpan }\end{array}$ & Berhasil \\
\hline 4 & $\begin{array}{l}\text { Pengguna melakukan } \\
\text { daftar User dan operator }\end{array}$ & $\begin{array}{l}\text { Pengguna dapat masuk ke } \\
\text { halaman profile dan data } \\
\text { pengguna tersimpan serta } \\
\text { menampilkan data } \\
\text { operator yang tersimpan }\end{array}$ & $\begin{array}{l}\text { Pengguna dapat } \\
\text { masuk ke halaman } \\
\text { profile dan data } \\
\text { pengguna tersimpan } \\
\text { serta menampilkan } \\
\text { data operator yang } \\
\text { tersimpan }\end{array}$ & Berhasil \\
\hline 5 & $\begin{array}{l}\text { User melakukan daftar } \\
\text { operator dan } \\
\text { memasukkan data } \\
\text { dengan benar }\end{array}$ & $\begin{array}{l}\text { User dapat masuk ke } \\
\text { halaman profile dan data } \\
\text { operator tampil pada } \\
\text { halaman profile }\end{array}$ & $\begin{array}{l}\text { User dapat masuk ke } \\
\text { halaman profile dan } \\
\text { data operator tampil } \\
\text { pada halaman profile }\end{array}$ & Berhasil \\
\hline 6 & $\begin{array}{l}\text { User memilih operator } \\
\text { dan melakukan request } \\
\text { produk serta } \\
\text { memasukkan data } \\
\text { dengan benar }\end{array}$ & $\begin{array}{l}\text { User dapat mengirimkan } \\
\text { data request ke operator }\end{array}$ & $\begin{array}{l}\text { User dapat } \\
\text { mengirimkan data } \\
\text { request ke operator }\end{array}$ & Berhasil \\
\hline 7 & $\begin{array}{l}\text { User melakukan filter } \\
\text { data } \text { operator saat } \\
\text { request produk }\end{array}$ & $\begin{array}{l}\text { Data operator tampil } \\
\text { sesuai dengan data yang } \\
\text { dimasukkan }\end{array}$ & $\begin{array}{l}\text { Data operator tampil } \\
\text { sesuai dengan data } \\
\text { yang dimasukkan }\end{array}$ & Berhasil \\
\hline 8 & $\begin{array}{l}\text { User melakukan } \\
\text { pencarian produk, } \\
\text { operator atau artikel } \\
\text { pada form pencarian dan } \\
\text { memasukkan data } \\
\text { dengan benar }\end{array}$ & $\begin{array}{l}\text { Data operator, data } \\
\text { produk atau artikel tampil } \\
\text { sesuai dengan data yang } \\
\text { dimasukkan }\end{array}$ & $\begin{array}{l}\text { Data operator, data } \\
\text { produk atau artikel } \\
\text { tampil sesuai dengan } \\
\text { data yang dimasukkan }\end{array}$ & Berhasil \\
\hline 9 & $\begin{array}{l}\text { User membuka data } \\
\text { penawaran yang } \\
\text { dikirimkan operator } \\
\text { dalam bentuk file.PDF }\end{array}$ & $\begin{array}{l}\text { File .PDF dapat tampil } \\
\text { dengan benar }\end{array}$ & $\begin{array}{l}\text { File .PDF dapat tampil } \\
\text { dengan benar }\end{array}$ & Berhasil \\
\hline 10 & $\begin{array}{l}\text { Operator menambahkan } \\
\text { data produk }\end{array}$ & $\begin{array}{l}\text { Operator dapat } \\
\text { menyimpan data produk }\end{array}$ & $\begin{array}{l}\text { Operator dapat } \\
\text { menyimpan data } \\
\text { produk }\end{array}$ & Berhasil \\
\hline 11 & $\begin{array}{l}\text { Operator melakukan } \\
\text { kirim penawaran kepada } \\
\text { User yang melakukan } \\
\text { request produk }\end{array}$ & $\begin{array}{l}\text { Operator dapat } \\
\text { mengirimkan data } \\
\text { penawaran kepada User }\end{array}$ & $\begin{array}{l}\text { Operator dapat } \\
\text { mengirimkan data } \\
\text { penawaran kepada } \\
\text { User }\end{array}$ & Berhasil \\
\hline
\end{tabular}




\begin{tabular}{|c|l|l|l|l|}
\hline No. & \multicolumn{1}{|c|}{ Skenario Pengujian } & \multicolumn{1}{|c|}{ Hasil Diinginkan } & \multicolumn{1}{|c|}{ Hasil Dicapai } & Kesimpulan \\
\hline 12 & $\begin{array}{l}\text { User melakukan } \\
\text { verifikasi } \text { email }\end{array}$ & $\begin{array}{l}\text { User dapat masuk ke } \\
\text { halaman profile dan } \\
\text { menghilangkan tampilan } \\
\text { data belum terverifikasi }\end{array}$ & $\begin{array}{l}\text { User dapat masuk ke } \\
\text { halaman profile dan } \\
\text { menghilangkan } \\
\text { tampilan data belum } \\
\text { terverifikasi }\end{array}$ & Berhasil \\
\hline 13 & $\begin{array}{l}\text { Filter harga terhadap } \\
\text { jenis trip yang sama }\end{array}$ & $\begin{array}{l}\text { User dapat menemukan } \\
\text { paket wisata dengan } \\
\text { harga yang sesuai dengan } \\
\text { inputan dan trip }\end{array}$ & $\begin{array}{l}\text { User masih } \\
\text { menemukan harga } \\
\text { untuk semua trip }\end{array}$ & $\begin{array}{l}\text { Belum } \\
\text { berhasil }\end{array}$ \\
\hline
\end{tabular}

$$
\text { Akurasi tingkat pengujian }=\frac{\text { Pengujian yang berhasil }}{\text { Total pengujian }} \times 100 \%=\frac{12}{13} \times 100 \%=92 \%
$$

Berdasarkan pengujian didapatkan keberhasilan dari fungsional program dan ini menujukan aplikasi dapat digunakan untuk mengakomodir proses memberikan kemudahan untuk mendapatkan informasi bagi masyarakat khususnya yang ingin mengetahui paket paket wisata. Secara keseluruhan $92 \%$ pengujian berhasil dilakukan dengan menggunakan metode blackbox.

\section{KESIMPULAN}

Aplikasi marketplace tour dan travel akan mempermudah masyarakat dalam melakukan pencarian paket tour wisata sesuai dengan kondisi keuangan sehingga mereka tidak kesulitan lagi mencari tour operator secara manual yang memakan waktu lama untuk mendapatkan paket tour wisata yang sesuai. Secara pengujian menggunkaan metode blackbox menunjukan fungsional dari aplikasi yang dibangun $100 \%$ berhasil di lakukan.

\section{DAFTAR PUSTAKA}

Banfield, R., Lombardo, C. T. \& Wax, T., 2016. Design Sprint. 3rd ed. Canada: O'Reilly Media, Inc.

Brahmanto, E. (2015). Magnet Paket Wisata Dalam Menarik Kunjungan Wisatawan Asing Berkunjung Ke Yogyakarta. JURNAL MEDIA WISATA: Wahana Informasi Pariwisata, 13(2).

Djirdeh, H., 2018. Fullstack Vue The Complete Guide To Vue.js. California: Fullstack.io.

Kadir, A. (2010). Mudah Mempelajari Database MySQL. Yogyakarta: Penerbit ANDI.

Silva, T. S. D., Estacio, B., Kroll, J. \& Fontana, R. M., 2017. Agile Methods. Switzerland: Springer Nature.

Sukamto, R. A., \& Shalahuddin, M. (2016). Rekayasa Perangkat Lunak. Bandung: Informatika.

Winarno, E. (2014). 24 Jam Belajar PHP. Jakarta: PT Elex Media Komputindo 